\title{
PELUANG USAHA SERTA KERJA AKIBAT KEHADIRAN WISATAWAN PADA KOMUNITAS TUGU
}

\author{
Bussiness and Job Opportunities Due to The Presence of Tourist in Tugu Community
}

\author{
Melly Amalia*), Titik Sumarti, dan Nurmala K. Pandjaitan \\ Departemen Sains Komunikasi dan Pengembangan Masyarakat, Fakultas Ekologi Manusia, IPB \\ *)Email : meuli_tea@yahoo.com
}

\begin{abstract}
The presence of Arabian tourists in Tugu is to fill their leisure time. Unconsciously, the presence of Arabian tourists in Tugu community have an impacts on business opportunities and job opportunities in the rural community. This conditions raises the question research, such as 1) how the presence of Arabian tourists in Tugu Village, 2) whether a change in the livelihood activity to the Tugu commnity. The purpose of this research is to identify the business opportunities and job opportunities in rural communities, due to the presence of Arab tourist, along with the development of the tourism industry. The respondents were village officials, community leaders and Tugu community member. The data were collected by conducting in-depth interviews and observations. The research location was in the village of Tugu sub Cisarua, Bogor regency West Java. The collected data were analyzed by using qualitative methods. In the end, The results showed that the presence of Arab Tourist provided business and job opportunities, resulting in a change of the economic level in the community.
\end{abstract}

Keywords: business opportunities, economic impact, job opportunities, tourist

\section{ABSTRAK}

Kehadiran wisatawan Arab di Tugu adalah untuk mengisi waktu luang mereka. Tanpa disadari, kehadiran wisatawan Arab dalam masyarakat Tugu memiliki dampak pada peluang bisnis dan peluang kerja di masyarakat pedesaan. Kondisi ini menimbulkan pertanyaan penelitian, seperti 1) bagaimana kehadiran wisatawan Arab di Tugu Desa, 2) apa perubahan dalam aktivitas mata pencaharian ke commnity Tugu. Tujuan dari penelitian ini adalah untuk mengidentifikasi peluang bisnis dan peluang kerja di masyarakat pedesaan, karena kehadiran turis Arab, seiring dengan perkembangan industri pariwisata. Responden terdiri dari aparat desa, tokoh masyarakat dan anggota masyarakat Tugu. Data dikumpulkan dengan melakukan wawancara mendalam dan observasi. Lokasi penelitian di Desa Tugu Cisarua sub, Kabupaten Bogor - Jawa Barat. Data yang terkumpul dianalisis dengan menggunakan metode kualitatif. Pada akhirnya, Hasil penelitian menunjukkan bahwa kehadiran Arab Tourist memberikan peluang usaha dan lapangan kerja, mengakibatkan perubahan tingkat ekonomi di masyarakat.

Kata kunci: dampak ekonomi, peluang bisnis, peluang kerja, wisata

\section{PENDAHULUAN}

Kunjungan wisatawan asing yang datang ke Indonesia mengalami kenaikan seperti yang telah dilansir oleh www. metrotvnews.com, pada tanggal 1 Agusutus 2013, yang menyatakan pada periode Januari - Juni 2013 terjadi kenaikan sebesar 7,2\% jika dibandingkan dengan tahun 2012 pada periode yang sama. Hal ini juga dinyatakan oleh Menteri Pariwisata dan Ekonomi Kreatif Indonesia, bahwa kunjungan wisatawan mancanegara ke Indonesia mengalami kenaikan dari 3.876.310 orang pada tahun 2012 menjadi 4.154.478 pada tahun 2013. Daerah Puncak di Kabupaten Bogor Provinsi Jawa Barat merupakan daerah pariwisata yang terkenal di Indonesia, karena memiliki daya tarik tersendiri bagi para wisatawan. Baik oleh wisatawan lokal maupun wisatawan asing. Wisatawan asing yang paling banyak terlihat di Puncak adalah wisatawan asal Timur Tengah, yang kemudian banyak diberitakan jika mereka itu adalah wisatawan asal Arab Saudi.

Keberadaan turis Arab Saudi di Puncak memberikan peluang bagi masyarakat setempat. Baik pelang berusaha maupun peluang kerja bagi komunitas setempat. Kebutuhan akan makanan, transportasi, dan tempat tinggal menjadi peluang tersendiri atas keberadaan turis Arab Saudi, hal ini terlihat dari adanya berbagai jenis usaha yang terdapat di sekitar desa Tugu seperti adanya restoran, swalayan, rental mobil, dan vila. Pada periode 2012 menurut Passenger Exit Survey, Departemen Budaya dan Pariwisata, wisatawan asal Arab Saudi menghabiskan uangnya di Indonesia sebesar $1.424,47$ US\$. Itu artinya dengan pengeluaran 
tersebut telah memberikan kontribusi bagi perekonomian masyarakat Indonesia.

Senada dengan pernyataan diatas, bahwa kehadiran turis Arab Saudi memberikan dampak yang besar bagi komunitas desa Tugu, bahkan bagi pemerintah Kabupaten Bogor. Menurut mantan Kepala Dinas Budaya dan Pariwisata Kabupaten Bogor, perputaran uang dikawasan puncak mencapai triliunan, sehingga terjadi pertumbuhan ekonomi yang luar biasa. Sedangkan menurut salah satu staf Dinas Budaya dan Pariwisata Kabupaten Bogor, kawasan puncak setiap tahun menjadi kawasan penyumbang PAD terbesar, yakni sekitar 20 persen dari total PAD wisata yang masuk.

Banyaknya wisatawan disuatu tempat akan memberikan dampak, diantaranya pada kegiatan ekonomi masyarakat, dengan timbulnya keberagaman aktifitas nafkah. Keberagaman aktifitas nafkah yang ditemui di desa Tugu jika dikaitkan dengan keberagaman aktifitas nafkah menurut Sconez (1998) dapat digolongkan berdasarkan strategi nafkah, yaitu : 1) intesifikasi dan ekstensifikasi, 2) diversifikasi, 3) migrasi permanen dan sirkular.

Berdasarkan penjelasan di atas penelitian ini bertujuan untuk mengkaji dampak yang ditimbulkan dari keberadaan turis Arab, pada peluang bekerja dan berusaha masyarakat desa Tugu, sehingga muncul pertanyaan :

1. bagaimana keberadaan turis Arab di desa Tugu?

2. apakah terjadi perubahan aktifitas nafkah pada komunitas desa Tugu?

\section{Kerangka Pemikiran}

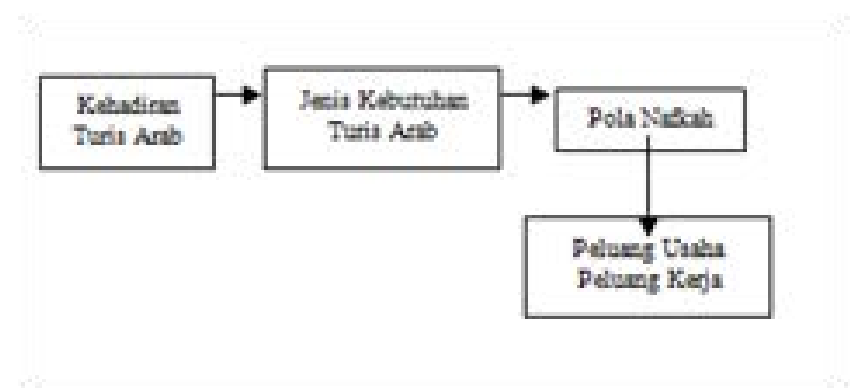

Gambar 1. Kerangka Pemikiran

Kedatangan mereka tidak hanya sekedar berlibur, ada juga kedatangannya untuk berinvestasi dan mengembangkan bisnisnya di Indonesia. Hal ini ditandai dengan adanya peluang usaha yang terbuka bagi masyarakat sekitar. Semakin banyak turis Arab yang datang, semakin besar pula keinginan mereka untuk mendapatkan kebutuhannya. Kebutuhan tersebut berkaitan dengan pola konsumsi terhadap barang dan jasa, berdasarkan kebutuhannya itu pada akhirnya memberikan peluang bagi masyarakat untuk membuka peluang usaha dan peluang kerja.

Peluang usaha dan peluang kerja terbuka bukan hanya untuk warga setempat, tetapi juga terbuka untuk warga di luar komunitas Tugu. Sebagian besar usaha yang ada adalah usaha yang dimiliki oleh orang-orang diluar komunitas. Motel, Hotel, villa sampai pada rental mobil, warnet, tokotoko yang menjual barang-barang kebutuhan khas Arab pun tersedia di sana, money changer, bahkan café-café khas Arab. Banyaknya jenis usaha pada akhirnya memberikan peluang pada masyarakat setempat yang hanya memiliki modal fisik, untuk mendapatkan pekerjaan seperti penjaga vila, pegawai hotel, supir, pelayan travel, dan lain-lain.

\section{METODOLOGI}

Penelitian ini dilaksanakan di desa Tugu, kecamatan Cisarua, kabupaten Bogor - Jawa Barat. Pemilihan desa Tugu sebagai lokasi penelitian karena wilayah ini terkenal dengan banyaknya turis Arab yang menetap sementara selama masa liburan mereka. Informan utama pada penelitian ini adalah aparat desa, tokoh masyarakat dan masyarakat. Pemilihan informan penelitian dilakukan dengan teknik purposif dan snowball sampling. Pengumpulan data dilakukan dengan menggunakan wawancara mendalam (indepth interview) dan obeservasi.

Teknik analisis data yang digunakan dalam penelitian ini adalah mengunakan teknik analisis data kualitatif. Penelitian kualitatif merupakan metode-metode untuk mengeksplorasi dan memahami makna yang oleh sejumlah individu atau sekelompok orang dianggap berasal dari masalah sosial atau kemanusiaan. Penelitian kualitatif menampilkan data berupan deskriptif.

\section{HASIL DAN PEMBAHASAN}

\section{Keberadaan Turis Arab di Komunitas}

Desa Tugu terletak di kecamatan Cisarua, Kabupaten Bogor Jawa Barat. Desa Tugu terbagi menjadi dua wilayah yaitu Tugu Utara dan Tugu Selatan yang terpisah oleh jalan raya jalur Bogor - Puncak - Cianjur (BOPUNCUR). Sepanjang jalur tersebut sering disebut sebagai daerah Warung Kaleng - Sampay, banyak terdapat berbagai macam jenis usaha, seperti Restoran, berbagai macam toko yang menjual makanan, pulsa, gahru (kayu wangi), travel, dan lain-lain. Berbagai macam jenis usaha ini ada dikarenakan banyaknya turis Arab yang tinggal sementara di vila-vila di desa Tugu, sehingga mereka membeli berbagai macam kebutuhannya di Warung Kaleng - Sampay.

Keberadaan turis Arab di Indonesia, menurut tokoh pemuda desa Tugu dimulai sejak tahun 1980-an, mereka melakukan kunjungan untuk syi'ar agama Islam. Menurut data BPS kedatangan turis Timur Tengah yang datang ke Indonesia dari tahun ke tahun mengalami peningkatan, walaupun terjadi penurunan di tahun 2012 sebesar 9,27 persen. Penuunan tersebut menurut UNWTO (World Tourism Organization) disebabkan oleh gejolak politik Timur Tengah yang memanas diakhir tahun 2011 hingga tahun 2012

Keberadaan turis Arab di komunitas tujuannya untuk mengisi waktu liburan mereka. Menurut mereka Indonesia menjadi pilihan mereka karena kurs rupiah yang relatif lebih murah, cuaca puncak yang sejuk, orang-orangnya yang ramah dan hangat, persamaan budaya Islam, dan tersedianya berbagai macam kebutuhan khas negaranya. Namun ada juga yang datang ke Indonesia tujuannya untuk melakukan aktifitas bisnis, seperti membuka restoran, travel hingga menyewakan vila.

Tidak semua kegiatan yang dilakukan oleh turis hanya terbatas pada jalan-jalan dan menikmati keindahan puncak saja. Tetapi juga mereka melakukan aktifitas negatif, seperti mabuk-mabukan, menyewa PSK, berpesta dan lain-lain. Pariwisata dimana pun tidak bisa dilepaskan dari daya tarik 
wisata dan daya tarik wanita. Perempuan menjadi "asset" bagi daya tarik wisata, selain keindahan alam. Contohnya saja di Thailand yang pada akhirnya menjadikan "pelayanan personal" sebagai salah satu komoditas terbesar negaranya. Daya tarik wanita menjadi hal utama untuk meningkatkan pendapatan Negara, tanpa melihat dampak sosial yang akan ditimbulkannya pada jangka panjang.

Perkembangan industri pariwisata tidak bisa dipisahkan dari pelacuran yang merupakan ekspansi turisme di Asia Tenggara yang sudah berlangsung sejak dekade 1960-an (Truong, 1992). Begitu pun yang terjadi di Puncak, dimana PSK hadir sebagai daya tarik para wisatawan.

Turis yang berada di Puncak mayoritas berasal dari Arab Saudi. Kedatangan mereka mulai ramai di tahun 1990 , awalnya kedatangan mereka adalah musiman, yaitu pada liburan musim panas sekitar bulan Juni hingga Agustus. Namun, di tahun 2000 pola berlibur mereka berubah hal ini seiring dengan kebijakan pemerintahnya yang menerapkan sistem liburan dengan cara bergiliran dan hal ini berdampak pada pola kunjungan turis Arab. Kini sepanjang tahun mereka bergantian datang ke Kawasan Puncak, tanpa terbatas oleh musim panas.

Mereka terbagi kedalam 3 tipologi, yaitu :

1. Keluarga, biasanya tujuan utamanya hanya benar-benar untuk mengisi waktu berlibur. Kegiatan mereka pun dihabiskan dengan cara berjalan-jalan, mengunjungi tempat wisata yang ada di kota Bogor dan sekitarnya.

2. Kelompok, biasanya terdiri dari anak-anak muda, biasanya mereka berlibur minimal berdua hingga berlima. Mereka pun terbagi lagi dalam dua kategori. Kelompok pertama biasanya mereka baru pertama kali datang ke Indonesia, sehingga kegiatan yang dilakukan pun hanya sebatas berwisata mengunjungi daerah wisata. Kelompok kedua adalah kelompok yang tidak hanya ingin menikmati keindahan alam saja, tetapi mereka juga menghendaki wisata lainnya. Mereka biasanya sudah berulang-ulang datang ke Indonesia, sehingga mereka lebih mengetahui situasi lingkungan. Kegiatan yang dilakukan pun cenderung kegiatan yang sifatnya hanya untuk bersenang-senang saja. Selain mengunjungi tempat wisata, biasanya mereka juga menghabiskan waktu bersama teman-temannya di vila dengan membuat pesta dengan lantunan musik disko Arab. Ketika berpesta biasanya mereka tidak luput dari minuman keras dan wanita.

3. Individu, biasanya adalah orang yang sudah berkalikali datang ke Puncak. Tujuannya adalah untuk bisnis dan beristirahat di usia senja mereka. Tidak sedikit diantara mereka yang sudah dianggap menjadi bagian dari Desa Tugu, karena sudah bisa bahasa Indonesia bahkan bahasa Sunda.

\section{Pola Aktifitas Nafkah}

Mata pencaharian warga desa Tugu awalnya sebagai petani, namun seiring dengan perkembangan pariwisata di kawasan Puncak di awal tahun 1990 telah menyebabkan terjadinya alih fungsi lahan, dari lahan pertanian menjadi bangunan permanen seperti pemukiman penduduk dan vila. Bergesernya alih fungsi lahan dari pertanian menjadi pemukiman dan vila, juga mempengaruhi bergesernya pola nafkah warga desa Tugu, dimana sebagian besar warga bekerja di bidang pariwisata.

Desa mengalami ketimpangan akses terhadap lapangan pekerjaan, sebagai akibat dari minimnya lahan pertanian, sehingga menyebabkan terjadinya diversifikasi (perluasan) terhadap sistem nafkah di pedesaan. Seperti yang dijelaskan oleh Sconez (1998) bahwa beragamnya pola aktifitas nafkah di desa Tugu, dapat dilihat berdasarkan keberagaman pola aktivitas nafkah yang digolongkan berdasarkan strategi nafkah, diantaranya:

1. Dilakukannya intensifikasi (melakukan penambahan sumber daya manusia seperti tenaga kerja) dan ekstensifikasi (melakukan perluasan bidang usaha). Berkembangnya pariwisata berpengaruh pada pertanian di desa Tugu. Petani tidak bisa melakukan perluasan lahan pertanian, akibat dibangunnya vilavila dan pemukiman warga. Sehingga intesifikasi dan ekstensifikasi tidak dilakukan di desa Tugu karena minimnya lahan pertanian.

2. Pola aktifitas nafkah ganda, dengan melakukan diversifikasi pekerjaan dengan menambah jenis pekerjaan baru. Minimnya lahan pertanian menunjukkan sulitnya akses terhadap pekerjaan sebagai petani, oleh karena itu diperlukan diversifikasi aktivitas nafkah ganda. Menambah jenis pekerjaan baru tidak hanya dilakukan untuk diri sendiri, tetapi juga melibatkan keluarga. Misalnya suaminya sebagai petani, karena terjadi pergeseran mata pencaharian sebagai akibat dari meningkatnya industri pariwisata, maka pekerjaannya berubah ke jenis pekerjaan yang berkaitan dengan pariwisata. Suami tidak bekerja sendiri tetapi juga melibatkan istri untuk juga bekerja sebagai hadamah (tukang masak). Ini menunjukkan terdapatnya diversifikasi terhadap pekerjaan.

3. Melakukan migrasi sebagai upaya untuk melakukan perpindahan baik secara permanen maupun sirkuler, karena ingin mencari sumber nafkah baru di tempat lain. Migrasi dilakukan oleh orang-orang yang menggantungkan hidupnya pada industri pariwisata di Puncak. Seperti yang dilakukan oleh para perempuan asal Jawa Tengah, yang rela bermigrasi untuk mendapatkan peluang berusaha untuk menjadi pedangang baju keliling.

Selain analisis berdasarkan strategi nafkah Sconez (1998), peneliti juga menganalisis berdasarkan pengamatan dan observasi di lapangan, peneliti melihat strategi nafkah baru berdasarkan pola normatif dan ilegal seperti yang di bahas oleh Dharmawan (2006), dijelaskan bahwa strategi nafkah bisa dilakukan dengan peaceful ways atau dengan non peaceful. Secara normatif (peaceful ways) didalamnya terjadi kegiatan produksi, pertukaran, migrasi hingga terbentuknya jaringan sosial, hal ini penulis jelaskan melalui sumber pendapatan yang paling banyak menyerap tenaga kerja dan pendapatan masyarakat.

Ada pun jenis usaha yang menjadi sumber pendapatan masyarakat setempat diantaranya vila, home stay, warung, ojek, maktab, restoran dan supir/guide. Peluang usaha di desa Tugu tidak hanya terbuka untuk strategi nafkah yang normatif saja tetapi juga pada akhirnya membuka peluang usaha yang bersifat ilegal (non peaceful), munculnya jenis pekerjaan yang melanggar nilai dan norma komunitas 
setempat seperti : adanya para Pekerja Seks Komersil (PSK) dan pengemis. Pekerjaan tersebut diminati oleh para pendatang, seperti warga Cianjur, Sukabumi, Indramayu, Jawa Tengah dan lain sebagainya.

Warung Kaleng adalah kawasan pusat bisnis yang berkaitan dengan turis Arab. Semua jenis usaha yang terdapat di Warung Kaleng merupakan jenis usaha yang semuanya memenuhi kebutuhan turis Arab. Mereka menjual berbagai kebutuhan orang Arab, selain itu juga mereka menyediakan jasa. Kemajuan perekonomian masyarakat tentunya mendorong berbagai macam peningkatan kehidupan masyarakat, diantaranya peningkatan penghasilan, yang juga berarti peningkatan kesejahteraan masyarakat. Besarnya potensi pariwisata puncak memberikan iklim baik bagi perekonomian komunitas Tugu. Munculnya berbagai macam peluang usaha dan peluang kerja menjadi salah satu peningkatan yang luar biasa.

Warung Kaleng terletak disepanjang jalan yang membelah desa Tugu Utara dan Tugu Selatan. Sepanjang jalanan tersebut terdapat berbagai macam jenis usaha, diantaranya sebagai berikut :

Tabel. 1 Jenis Usaha yang Terdapat di Warung Kaleng

\begin{tabular}{lll}
\hline No. & Nama Jenis Usaha & Jumlah \\
\hline 1. & Warung Kelontong & 4 \\
2. & Penjual Pulsa & 12 \\
3. & Warung Bakso & 2 \\
4. & Maktab/Travel & 8 \\
5. & Barber Shop/Salon & 2 \\
6. & Warnet & 2 \\
7. & Mini Market & 3 \\
8. & Penjual Oleh-Oleh & 28 \\
9. & Penjual Buah & 3 \\
10. & Fotokopi & 1 \\
11. & Rumah Makan Arab & 7 \\
12. & Pangkalan Rental Mobil & 3 \\
13. & Rumah Makan Biasa (Warteg, & 4 \\
\multicolumn{3}{l}{ Rumah Makan Padang, Resto- } \\
Sumber: Data Observas1 Lapangan, 2013.
\end{tabular}

\section{Peran Serta Pariwisata Dalam Aktifitas Ekonomi}

Ketimpangan akses terhadap sumber nafkah yang ada menyebabkan terjadinya perluasan sistem nafkah dipedesaan (Ellis, 2000). Sistem nafkah sendiri terdiri dari asset, aktifitas dan akses. Munculnya aktifitas nafkah baru memberikan peluang bagi masyarakat sekitar untuk mendapatkan peluang kerja. Lahan bagi masyarakat pedesaan merupakan modal alam dan modal fisik yang menjadi sumber nafkah utama masyarakat. Ketika lahan pertanian semakin menyempit, pada saat itu pula masyarakat Tugu mengalami kesulitan terhadap akses lapangan kerja. Kehadiran turis Arab menimbulkan modal finansial yang bermanfaat bagi terjadinya perluasan sistem nafkah di kampung Tugu. Meningkatnya aktifitas nafkah tentunya akan diikuti dengan meningkatnya penghasilan, yang pada akhirnya masyarakat mampu meningkatkan kesejahteraan hidupnya.

Peningkatan kesejahteraan ditandai dengan minimnya angka masyarakat yang berkunjung ke puskesmas dari biasanya minimal puskemas melayani 50 orang pasien, sejak ramai turis Arab, justru hanya 20 orang pasien yang dilayaninya tiap hari. Selain itu juga warga mampu melakukan perubahan pada mata pencahariannya, misalnya dari yang tadinya tukang ojek akhirnya menjadi supir dan memiliki mobil. Bahkan tingkat pengangguran pun bisa ditekan, meskipun tidak ada data pasti, namun mereka mengklaim jika para pemudanya semua bekerja. Tidaklah sulit mendapatkan pekerjaan selama memiliki skill, pandai bahasa Arab, dari mulai anak-anak hingga orang tua pun bisa mendapatkan penghasilan.

Sebagian besar modal yang digunakan oleh komunitas desa Tugu adalah modal manusia, sebagai modal diri. Komunitas mengkontribusikan tenaganya untuk mendapatkan penghasilan. Selain itu juga komunitas Desa Tugu juga sebagian mengandalkan modal sosialnya. Hubungan sosial yang mereka bina dengan turis Arab, memberikan peluang bagi masyarakat. Kemudahan akses turis Arab terhadap sumberdaya menyebabkan keberadaan mereka makin kuat, karena ditunjang oleh keberadaan fasilitas yang diusahakan oleh warga sekitar maupun oleh paran investor.

Pola aktifitas dalam sistem nafkah baru di Desa Tugu berbasis sumber daya non-alam, kegiatan yang dijalankannya berupa kegiatan perdagangan. Banyaknya turis Arab, menginspirasi para pengusaha kecil dan menengah hingga pengusaha besar melakukan investasi yang berkaitan dengan pemenuhan kebutuhan turis. Mulai dari hanya pedagang kecil yang menjual kebutuhan seharihari, hingga investor yang memiliki vila. Terbukanya peluang usaha di Desa Tugu tentunya berdampak pada terbukanya peluang kerja. Peluang usaha dan peluang kerja tidak hanya dimanfaatkan oleh penduduk sekitar Desa Tugu saja tetapi juga dimanfaatkan oleh para penduduk di luar desa, bahkan dimanfaatkan oleh warga negara asing, yang berinvestasi mulai dari distributor makanan, pemilik maktab(kantor travel) hingga pemilik vila berkelas. Seperti yang tertera dalam tabel dibawah ini, dimana dijelaskan terdapat 6 (enam) jenis usaha yang paling menonjol di Desa Tugu berikut daya tampung terhadap tenaga kerja. Sebanyak 2.510 jiwa terserap dalam 1.244 lapangan pekerjaan yang tersedia di Desa Tugu.

Tabel 2. Jenis Usaha yang Terdapat di Warung Kaleng

\begin{tabular}{|c|c|c|c|}
\hline No. & Nama Usaha & Jumlah & $\begin{array}{l}\text { Serapan Tena- } \\
\text { ga Kerja }\end{array}$ \\
\hline 1 & Vila/hotel & 711 & 1550 \\
\hline 2 & Restoran & 22 & 93 \\
\hline 3 & Warung/mini market & 463 & 770 \\
\hline 4 & Travel/Maktab & 8 & 32 \\
\hline 5 & Warung pulsa & 12 & 20 \\
\hline 6 & Pusat Oleh-oleh & 28 & 45 \\
\hline $\begin{array}{l}\text { TO O- } \\
\text { TAL }\end{array}$ & & 1.244 & 2.510 \\
\hline
\end{tabular}

Selatan 
Timbulnya sumber pendapatan baru bagi penduduk yang berasal dari meningkatnya sektor pariwisata puncak karena kehadiran turis Arab, diantaranya :

Pertama, jasa vila atau penginapan. Menurut keterangan Bapak Rul, terdapat $20 \%$ dari warga yang memiliki usaha vila, $60 \%$ dimiliki oleh pendatang lokal, dan sekitar $10-$ $20 \%$ dimiliki oleh warga Arab. Lahan pertanian sekitar $40-50 \%$ ditanami oleh tanaman organik, sayuran dan bunga. Tanaman organik dan sayuran biasanya memenuhi kebutuhan masyarakat Jakarta, hotel dan restoran. Tanaman bunga mampu memenuhi kebutuhan bunga dalam negeri juga untuk memenuhi pasar luar negeri.

Peluang usaha yang ada memberikan peluang kerja baik bagi warga setempat ataupun bagi warga pendatang. Bahkan yang bisa melihat peluang adanya usaha dan lapangan pekerjaan adalah orang-orang yang berada diluar Tugu.

Kedua, penyewaan rumah (home stay). Penduduk kampung Tugu yang memiliki rumah lain selain rumah induknya, sebagian besar menyewakan rumah-rumahnya kepada para imigran atau kepada para turis yang keuangannya minim, bahkan ada diantara mereka yang sanggup menyewakan rumahnya dan lalu mereka memilih mengontrak rumah tetangganya. Dalam satu bulan mereka bisa mengantongi penghasilan minimal Rp. 3.000.000,- sedangkan mereka hanya perlu rela berkorban untuk menyewa rumah ditetangganya yang hanya Rp. 500.000,-. Tentu saja hal ini mampu meningkatkan perekonomian keluarga.

Ketiga, warung atau toko. Di sekitar warung kaleng terdapat 463 warung atau toko. Mulai dari warung yang berjualan di pusat oleh-oleh hingga toko yang menjual berbagai macam kebutuhan turis Arab. Toko-toko besar yang menjual berbagai macam makanan yang di impor langsung dari Arab berada di pinggir jalan warung kaleng, terdapat 4 toko yaitu Toko Dn, Toko Ad, Toko Kbr, dan yang terbaru adalah Al-Shl.

Keempat, ojek motor. Ojek motor sebetulnya sudah ada dari tahun 1980-an, pada saat itu hanya melayani aktifitas warga saja. Namun dengan adanya turis Arab konsumen ojek pun bertambah. Demi menjaga ketertiban dan keamanan para tukang ojek. Ojek di Warung Kaleng pun memiliki organisasi yaitu Organisasi Ojek Warung Kaleng (O2WK) yang membawahi seluruh tukang ojek dikawasan Warung Kaleng. Anggotanya berkisar 200 (belum ada data pasti karena belum dilakukan pendataan ulang), 214 orang tersebut tersebar baik di depan gang maupun di vila-vila, jadi keberadaan mereka tidak terkonsentrasi didepan gang saja, tetapi juga ditempat-tempat lain yang berpotensi terdapat penumpang.

Kelima, Maktab. Maktab dalam bahasa Indonesia artinya kantor. Kantor disini maksudnya adalah travel agent dan money changer. Maktab biasanya dimiliki oleh orang Indonesia yang mayoritas bukanlah penduduk lokal. Seperti yang dimiliki oleh bapak Abd (50), Abd berasal dari Ambon dan mendirikan maktab, usahanya dimulai dari 10 tahun lalu. Sebelumnya Abd adalah supir yang bekerja di Arab Saudi. Ketika pulang ke Indonesia Abd memutuskan untuk membuka maktab money changer. Dalam menjalankan usahanya dibantu oleh keponakannya yang mengurusi usahanya dan merekrut satu pekerja lakilaki yang berasal dari warga sekitar.
Keenam, restoran. Banyaknya restoran di sepanjang jalan Tugu menambah ramai suasana Tugu. Restoran-restoran tersebut mayoritas dimiliki oleh orang Timur Tengah yang berinvestasi di Indonesia. Mereka biasanya menjadikan orang sekitar sebagai orang kepercayaan untuk dipakai "nama"-nya sehingga mereka mendapatkan kemudahan terhadap akses usaha.

Sedangkan untuk restoran kecil dimiliki oleh orang Indonesia, seperti rumah makan yang dimiliki oleh ibu Nng (40). Awal mula berdirinya restoran tersebut karena ibu Nng dan suami ingin memiliki penghasilan untuk keluarga. Ibu Nng tiga tahun lalu bekerja menjadi TKW uang hasil kerjanya dimanfaatkan untuk dijadikan modal, dengan mendirikan rumah makan sederhana yang khusus menyajikan makanan Arab. Keterampilannya memasak didapatkan dari pengalamannya, ketika bekerja di Arab Saudi. Menu yang disajikan biasanya Kabsah, Briani, Roti Hobus dan lain-lain. Dalam menjalankan bisnisnya suami istri ikut andil dalam kegiatan ekonominya. Suaminya ahli membuat roti dan ibu Nng khusus memasak. Hasil usahanya mampu menyekolahkan ketiga anaknya ke pesantren di Sukabumi. Mereka bukanlah penduduk asli, mereka adalah pendatang asal Cianjur.

Ketujuh, supir atau guide. Selain tukang ojek ada juga mata pencaharian sebagai supir. Supir tidak hanya berperan sebagai supir saja tetapi juga merangkap guide, mereka yang akan mengantar para turis keliling mengunjungi tempat-tempat wisata. Mereka terorganisir dalam satu organisasi yang bernama IGP (Ikatan Guide Puncak) yang berdiri sejak tahun 1997. IGP merupakan organisasi yang menaungi para supir dengan memberikan fasilitas dan keamanan dalam mencari nafkah. IGP membawahi 80 supir yang terdaftar dan memiliki KTA dan sekitar 400 orang yang merupakan anggota tidak tetap namun menginduk kepada IGP.

Kedelapan, pekerja seks. Seks dan pariwisata merupakan sesuatu yang tidak dapat dipisahkan. Seks seolah menjadi daya tarik tersendiri bagi keberadaan turis. Hal ini pun tidak hanya ditemukan di puncak saja tetapi juga di semua objek wisata. Seperti di Bali, Bali sebagai kota yang memiliki beragam aktifitas wisata, juga tidak terlepas dari aktifitas prostitusi. Prostitusi yang ditawarkan pun tidak hanya prostitusi perempuan tetapi juga prostitusi laki-laki. Bahkan di sekitar Seminyak terdapat club khusus homo seksual. Selain Bali, di Pangandaran pun terdapat "pasar wanita", yang setiap malamnya dijajakan para wanita-wanita cantik. Hal ini menunjukkan jika pariwisata tidak bisa terlepas dari aktifitas ekonomi yang terkait dengan seks.

Hal ini pun terjadi di Desa Tugu, dimana dengan bebasnya para PSK keluar masuk vila. Warga sebetulnya sudah pernah melakukan pembersihan terhadap PSK namun hal tersebut justru malah mengancam perkembangan pariwisata sekitar, berdampak pada sepinya tamu yang menyewa vila mereka. Pada akhirnya mereka membiarkan keberadaan PSK dengan catatan tidak mengganggu aktifitas warga dan juga tamu.

Prostitusi merupakan salah satu pekerjaan yang dianggap mudah, oleh sebagian perempuan yang tidak mampu bertahan hidup di kota. Hasil yang besar dalam waktu yang cepat tentu saja lebih menggiurkan, daripada mereka harus bekerja dengan waktu penuh dan hasil sedikit. Keberadaan mereka pun tidak bisa terlepas dari adanya permintaan 
akan jasa mereka. Prinsip supply - demand pun dijadikan alasan kenapa praktek-prakter prostitusi itu bisa berjalan langgeng. Para PSK sebagai pelaku prostitusi biasanya berasal dari luar komunitas, mereka berasal dari Cianjur, Sukabumi, Bandung, Karawang hingga Indramayu. Untuk biong biasanya mereka berasal dari warga sekitaran Tugu, namun bukan warga Tugu. Hal tersebut tentunya sangat bertolak belakang dengan norma ketimuran kita. Namun, jika kita melihat fenomena yang terjadi ketika seks menjadi daya tarik pariwisata tentu saja menjadi hal yang lumrah terjadi di industri pariwisata dimana pun.

\section{Pola Nafkah Non-Pertanian Komunitas Desa Tugu}

Sebelum adanya turis aktifitas ekonomi masyarakat hanya tergantung pada pertanian. Mulai dari sebagai petani penggarap hingga buruh tani. Pola nafkah non-pertanian (sektor dagang dan jasa) pada komunitas Desa Tugu adalah yang terbentuk setelah kehadiran turis Arab. Berdasarkan kebutuhan turis untuk memenuhi kebutuhannya seharihari, kebutuhan akan makan, tempat tinggal, penukaran uang, tiket perjalanan, transportasi, dan lain-lain, telah membuka peluang usaha, bagi komunitas setempat bahkan bagi masyarakat lain selain warga komunitas Tugu. Kepemilikan terhadap akses usaha biasanya didasarkan pada kepemilikan modal. Seperti yang tergambar pada bagan berikut:

\section{Tabel 3. Pola Nafkah Komunitas Desa Tugu}

\begin{tabular}{lll}
\hline No. & Jenis Usaha & Kepemilikan Usaha \\
\hline 1. & Vila & Luar dan dalam negeri \\
2. & Restoran & Luar dan dalam negeri \\
3. & Homestay & Masyarakat lokal \\
4. & Warung/toko & Masyarakat lokal \\
5. & Jasa (maktab, ojek, & Masyarakat lokal \\
\multicolumn{3}{l}{ Sumbir/guide, PSK) } \\
Sumber Data lapangan, 2013.
\end{tabular}

Berdasarkan tabel 4. mengenai pola nafkah pada komunitas Tugu bisa disimpulkan jika peluang usaha tidak hanya dinikmati oleh penduduk lokal saja, melainkan juga oleh pendatang, baik dari dalam maupun luar negeri. Vila dan restoran mayoritas dimiliki oleh orang luar komunitas seperti orang Jakarta bahkan ada yang dimiliki oleh orang Yaman. Dalam kepemilikan vila atau restoran yang dimiliki oleh orang luar negeri mayoritas mengantongi ijin resmi, tetapi ada juga sebagian yang memanfaatkan kedekatan dengan warga sekitar lalu bekerjasama sebagai orang kepercayaan atas kepemilikan vila atau restoran dalam upaya peminjaman nama. Kepemilikan usaha dengan modal besar biasanya dimiliki oleh pendatang sedangkan untuk jenis usaha yang sifatnya berskala kecil dan menengah dimiliki oleh warga lokal.

\section{KESIMPULAN DAN SARAN}

\section{Kesimpulan}

Keberadaan turis Arab di Desa Tugu memberikan pengaruh pada kehidupan komunitas Desa Tugu. Kebutuhan turis Arab akan makanan, transportasi, dan tempat tinggal memberikan pengaruh pada perekonomian masyarakat dengan berdirinya toko-toko yang menyediakan pangan khas Arab, restoran, rental mobil hingga vila. Keberadaan mereka memberikan pengaruh pada aktifitas sosial dan ekonomi masyarakat.

Proses industrialiasasi pariwisata yang berlangsung pada masyarakat agraris memberikan pengaruh besar pada masyarakat. Terjadinya perubahan yang dipengaruhi oleh adanya turis Arab, berdampak pada perubahan sosial dan ekonomi komunitas desa Tugu. Dampak pariwisata diantaranya mempengaruhi terjadinya perubahan pola aktivitas nafkah. Mulanya bermata-pencaharian sebagai petani kini berubah menjadi penggiat pariwisata. Meningkatnya industri pariwisata memberikan peluang bagi komunitas desa Tugu. Peluang tersebut berupa peluang kerja dan peluang usaha. Peluang tersebut tidak hanya dinikmati oleh warga sekitar, tetapi juga oleh pendatang bahkan oleh orang Arab-nya sendiri.

\section{Saran}

Keberadaan turis Arab Saudi memberikan pemasukan bagi masyarakat, PAD, bahkan bagi devisa negara. Turis merupakan aset yang harus "dijaga" dengan baik, untuk itu peningkatan pelayanan terhadap pariwisata di Indonesia sangatlah dibutuhkan. Dibutuhkan kesadaran dari para stakeholder untuk bersama-sama menciptkan iklim pariwisata yang kondusif.

Perlunya kontrol bagi pemerintah setempat hingga pemerintah pusat terkait dengan banyaknya peluang usaha dan peluang kerja pada masyarakat setempat. Terutama berkaitan dengan peluang usaha yang beberapa dimiliki oleh warga negara asing yang dikuasakan kepada masyarakat lokal. Meskipun keberadaan mereka sedikit menguntungkan bagi masyarakat setempat, namun usaha yang mereka jalankan telah merugikan Negara terkait dengan pemasukan pajak. Untuk itu pemerintah harus melakukan pengawasan terhadap jenis-jenis usaha di kawasan Tugu. Selain itu juga banyaknya PSK dan pengemis, seharus menjadi perhatian pemerintah setempat terkait munculnya Penyandang Masalah Kesejahteraan Sosial (PMKS) di desa Tugu.

\section{DAFTAR PUSTAKA}

Dharmawan, A.H. 2001. Farm Household Livelihood Strategies and Socio-economic Changes in Rural Indonesia. Disertasi : University of Gottingen, Jerman.

2006. Sistem Penghidupan Pedesaan : Menggali dan Mengenali Sosiologi Nafkah (Livelihood Sociology) Mazhab Bogor. Unpublished - Bogor.

2007. Sistem Penghidupan dan Nafkah Pedesaan : Pandangan Sosisologi Nafkah (Livelihood Sociology) Mahzab Barat dan Mahzab Bogor. Vol. 01, No. 02. Bogor : Sodality - Jurnal Transdisiplin Sosiologi, Komunikasi dan Ekologi Manusia.

Ellis, F. 2000. Rural Livelihoods and Diversity in Developing Countries. New York : Oxford University Press.

Departemen Budaya dan Pariwisata. 2012. Survei 
Penumpang Keluar. www.bps.go.id.

Pitana, I. dan Putu G. Gayatri. 2005. Sosiologi Pariwisata. Yogyakarta : ANDI.

Scones, I. 1998. Sustainable Rural Livelihood : a Framework For Analysis. UK : Sussex, Institute of Development Studies.

Soekanto, S. 1999. Sosiologi Suatu Pengantar (Edisi Baru Keempat 1990). Jakarta : PT. RajaGrafindo Persada.

Soemanto, R.B. 2010. Sosiologi Pariwisata. Jakarta : Universitas Terbuka.

Truong, T. 1992. Seks, Uang dan Kekuasaan : Pariwisata dan Pelacuran di Asia Tenggara. Jakarta : LP3ES.

Ramadhian, F. Majalah Info Puncak. Edisi Perdana Agustus 2012.

Widodo, S. 2011. Strategi Nafkah Berkelanjuatan Bagi Rumah Tangga Miskin di Daerah Pesisir. Makara Sosial Humaniora, vol. 15, No. 1, Juli 2011 : 10-20 